\title{
Effect of SOYXYL as a Dietary Protected Protein Supplement on the Reproductive Performance of Simmental Bulls
}

\author{
Bambang Waluyo Hadi Eko Prasetiyono ${ }^{1 *}$, Widiyanto ${ }^{1}$, Yon Soepri Ondho ${ }^{1}$, Agung Subrata ${ }^{1}$ and Hermawan \\ Setyo Widodo ${ }^{2}$ \\ ${ }^{1}$ Department of Animal Science, Faculty of Animal and Agricultural Sciences, Diponegoro University, Semarang, \\ Indonesia. \\ 2 Faculty of Animal Science, Jenderal Soedirman University, Purwokerto, Indonesia. \\ *Corresponding author email: bambangwhep@ymail.com
}

\begin{abstract}
The study aimed to evaluate the effect of SOYXYL as one of dietary protected protein supplement product in the rations on the reproduction performance of Simmental bulls. Twelve 5-year-old Simmental bulls were allotted to 4 treatment groups with 3 replications each, i.e. TO $=$ control ration (elephant grass +5 $\mathrm{kg} / \mathrm{head} /$ day commercial concentrate), $\mathrm{T} 1=$ control ration $+150 \mathrm{~g}$ protected protein supplement SOYXYL ( $3 \%$ concentrate), $\mathrm{T} 2=$ control ration $+300 \mathrm{~g}$ SOYXYL ( $6 \%$ concentrate) and T3= control ration $+450 \mathrm{~g}$ SOYXYL ( $9 \%$ of concentrate). The experiment lasted for 90 days. At the end of the experiment, semen and blood was collected and body weight gain was measured. The measured variables were sperm motility, sperm concentration, blood protein, blood urea and the concentration of testosterone. The results showed that SOYXYL supplementation particularly at 3 and $6 \%$ increased $(p<0.05)$ total plasma protein of bulls. SOYXYL supplementation at $3 \%$ from concentrate increased $(p<0.05)$ plasma urea concentration. Meanwhile, $6 \%$ and $9 \%$ SOYXYL increased $(p<0.05)$ the average daily gain of bulls as compared to control group. The bulls' sperm concentration increased $(p<0.05)$ after $3 \%$ SOYXYL supplementation but decreased $(p<0.05)$ after $6 \%$ and $9 \%$ treatment. The concentration of testosterone was higher $(p<0.05)$ in the bulls receiving $3 \%$ and $6 \%$ SOYXYL in the rations. Dietary supplementation of SOYXYL increased $(p<0.05)$ the sperm motility of Simmental bulls. In conclusion, dietary supplementation of SOYXYL at the level of $3 \%$ ration increased plasma protein, testosterone and sperm concentrations as well as sperm motility. However, $6 \%$ and $9 \%$ SOYXYL decreased the concentrations of sperm and testosterone.
\end{abstract}

Keywords: bulls, rumen-protected protein, reproduction, sperm quality, testosterone

\begin{abstract}
Abstrak. Penelitian ini bertujuan untuk mengevaluasi efek SOYXYL, sebagai salah satu produk suplemen protein terproteksi dari degradasi rumen, dalam ransum terhadap kinerja reproduksi sapi pejantan Simmental. Dua belas sapi pejantan Simmental berumur 5 tahun dialokasikan untuk 4 perlakuan dengan masing-masing 3 ulangan, yaitu: $\mathrm{TO}=$ ransum kontrol (rumput gajah $+5 \mathrm{~kg} /$ ekor $/$ konsentrat komersial), $\mathrm{T} 1=$ ransum kontrol + $150 \mathrm{~g}$ suplemen protein terproteksi SOYXYL ( $3 \%$ dari konsentrat), $\mathrm{T} 2=$ ransum kontrol $+300 \mathrm{~g}$ SOYXYL ( $6 \%$ dari konsentrat) dan T3 = ransum kontrol +450 g SOYXYL (9\% dari konsentrat). Percobaan berlangsung selama 90 hari. Pada akhir percobaan, semen dan darah dikumpulkan dan penambahan berat badan diukur. Variabel yang diukur termasuk motilitas sperma, konsentrasi sperma, protein darah, urea darah dan konsentrasi testosteron. Hasil penelitian menunjukkan bahwa suplementasi SOYXYL khususnya pada level 3 dan $6 \%$ meningkatkan $(p<0,05)$ total protein plasma sapi pejantan. Suplementasi SOYXYL pada $3 \%$ dari konsentrat menghasilkan peningkatan $(p<0,05)$ konsentrasi urea plasma. Pemberian SOYXYL khususnya pada level 6 dan $9 \%$ meningkatkan $(p<0,05)$ kenaikan bobot badan rata-rata harian sapi pejantan dibandingkan dengan kontrol. Pemberian 3\% SOYXYL meningkatkan $(p<0,05)$ konsentrasi sperma sapi pejantan, tetapi pada level 6 dan $9 \%$ menurunkan $(p<0,05)$ konsentrasi sperma sapi pejantan. Konsentrasi testosteron lebih tinggi $(p<0,05)$ pada sapi pejantan yang menerima 3 dan $6 \%$ SOYXYL dalam ransum. Suplementasi SOYXYL meningkatkan $(p<0,05)$ motilitas sperma sapi pejantan Simmental. Kesimpulannya, suplementasi SOYXYL pada level 3\% meningkatkan protein plasma, testosteron dan konsentrasi sperma serta motilitas sperma. Namun, suplementasi SOYXYL pada 6 dan $9 \%$ dari ransum menurunkan konsentrasi sperma dan testosteron.
\end{abstract}

Kata kunci: sapi pejantan, protein terproteksi dalam rumen, reproduksi, kualitas sperma, testosteron.

\section{Introduction}

Reproductive organs of bull play a crucial role in determining the reproductive performance of the herd. Any disorder in the bull's reproductive organs may implicate in the low level of conception and longer calving interval. In general, the reproductive 
performance of bulls may be reflected from sperm production, sperm quality and libido. The reproductive performance of bulls is influenced by several factors including individual factors, herd management and feed quality. With regard particularly to feed quality, the availability of high-quality protein is crucial for the optimum development of bull reproduction systems (Yasothai, 2014). From the nutritive utility point of view, the protection of protein (to avoid ruminal fermentation) needs to be conducted to optimize protein utilization in the post rumen digestive tract of bulls (Aboozar et al., 2013). For this reason, besides feeding bulls with degraded proteins in the rumen (to maximize rumen microbial protein), it is important to provide the undegraded protein supplement (called rumen undegraded protein [RUP] or rumen-protected protein) in the rations to increase the supply of amino acids for bulls (Tedeschi et al., 2015; Kumar et al., 2018). In the case of RUP, Prasetiyono et al. (2007) has found the SOYXYL as one of the rumenprotected protein supplements derived from extruded Soybean (Glycine max), which is beneficial for fattening of beef cattle. Yet, the potential of the product to improve the reproduction performance of bulls has never been documented.

Earlier study showed that the protected protein was beneficial in providing the high quality essential amino acids essential for supporting the reproduction performance of bulls (Prasetiyono et al., 2018). Also, protein and amino acids consumption significantly influenced the spermatogenesis and testosterone production in pubertal cattle (Rekwot et al. (1997). Traditionally, the commercial feeds for bulls in Indonesia contains unsubstantial amount of protected protein. Hence, this study investigated the effect of rumen-protected protein (SOYXYL) supplement in rations on the reproduction performance of Simmental bulls.

\section{Materials and Methods}

The study was conducted according to the standard procedure of raising livestock in the Law of the Republic of Indonesia No. 18 year 2009 regarding animal husbandry and health. The research used 12 five-year-old Simmental bulls with an average body weight of $700 \pm 2.75$ $\mathrm{kg}$. The bulls were raised for 90 days and placed individually in a cattle house facilitated with feeding and drinking equipment. Prior to dietary trial, all bulls were injected with vitamins $A, D$, $\mathrm{E}$, and $\mathrm{K}$ and adapted to the experimental feed for a month. The experimental feed consisted of elephant grass ( $15 \%$ dry matter) provided ad libitum and commercial concentrate $(85.25 \%$ dry matter, $5 \mathrm{~kg} / \mathrm{head} /$ day) containing $3.6 \%$ ash, $2.22 \%$ crude fat, $16.5 \%$ crude fiber, $71.26 \%$ total digestible protein (TDN) and $18.23 \%$ crude protein. Following adaptation, the Simmental bulls were allotted to 4 treatment groups, i.e. $\mathrm{TO}=$ control ration (elephant grass +5 $\mathrm{kg} / \mathrm{head} /$ day commercial concentrate), $\mathrm{T} 1=$ control ration $+150 \mathrm{~g}$ protected protein supplement SOYXYL ( $3 \%$ of concentrate), T2 = control ration $+300 \mathrm{~g}$ SOYXYL $(6 \%$ of concentrate) and $\mathrm{T} 3=$ control ration $+450 \mathrm{~g}$ SOYXYL ( $9 \%$ of concentrate). Prasetiyono et al. (2007) found the SOYXYL as one of the rumenprotected protein supplements derived from extruded Soybean (Glycine max). All treatments were replicated three times and run in a Completely Randomized Design (Steel et al., 1996).

At the end of the experiment, semen and blood were collected and body weight gain was measured. Semen was collected using an artificial vagina at $7 \mathrm{am}$, while blood was collected using a Venoject tube filled with ethylenediaminetetraacetic acid (EDTA). To produce plasma, the blood was centrifuged at 3,000 rpm for 10 minutes. The measured variables were sperm motility, sperm concentration, blood protein, blood urea and the concentration of testosterone. 
The sperm motility was assessed according to a procedure described by Toelihere (1993). The sperm motility was determined by observing the progressive movement of the sperm using a microscope and expressed as percentage (\%). The percentage of sperm motility was calculated by subtracting the total sperm with immobile sperm and then multiplied by $100 \%$. The concentration of sperm was determined according to the hemocytometer procedure. The concentration of urea and total protein in blood plasma was analyzed spectrophotometrically according to BerthelotReaction methods (Roseler et al., 1993). The testosterone concentration was determined using the enzyme-linked immunosorbent assay (ELISA) method with a testosterone kit (Voller et al., 1989).

The data collected from the present study were subjected to analysis of variance (ANOVA), and Duncan multiple range tests was further employed when the significant difference $(p<0.05)$ appeared among treatment groups. The analysis was conducted using SAS procedures (SAS, 2009).

\section{Results and Discussion}

\section{Total Plasma Protein}

The present study showed that dietary supplementation of rumen-protected protein (SOYXYL) at $3 \%$ and $6 \%$ increased $(p<0.05)$ total plasma protein of Simmental bulls (Table 1). In general, the levels of plasma total protein were within the normal range, i.e., $5.7-8.1 \mathrm{~g} / \mathrm{dL}$ in beef cattle (Radostits et al., 2007) and $8.42 \mathrm{~g} / \mathrm{dL}$ in Simmental bulls (Irfan et al., 2014). It was most likely that SOYXYL supplementation increased the amount of protein entering the post-rumen digestive tract; hence, increasing the availability of $\mathrm{N}$ in the intestine (Lapierre and Lobley, 2001). The increased absorption of $\mathrm{N}$ may therefore implicate in the elevated concentration of protein in the circulatory system of bulls. The latter inference was actually supported by $\mathrm{Ma}$ et al. (2011) demonstrating that feeding rumen-protected tryptophan resulting in increased plasma concentration of tryptophan in Cashmere goat. In our case, the absorbed $\mathrm{N}$ may be transferred to the liver for protein biosynthesis. The synthesized proteins may then enter the circulatory system (before reaching the muscle for deposit) leading to the elevated concentration of plasma total protein level. (Ahlman et al., 2001). It was also hypothesized in the present study that feeding SOYXYL increased non-ammonia nitrogen entering the post-rumen digestive tract, resulting in increased $\mathrm{N}$ available in the intestine and hence elevated the level of total protein in the bulls' plasma (Lapierre and Lobley 2001). Hristov et al. (2019) reported that rumen-protected protein-

Table 1. Effect of protected protein supplement on nutrient utility and reproduction performance of Simmental bulls

\begin{tabular}{|c|c|c|c|c|c|c|}
\hline \multirow{2}{*}{ Variables } & \multicolumn{4}{|c|}{ Treatment groups } & \multirow{2}{*}{ SEM } & \multirow{2}{*}{ Significance } \\
\hline & TO & T1 & T2 & T3 & & \\
\hline Sperm concentration $\left(10^{6} / \mathrm{ml}\right)$ & $1.23^{\mathrm{b}}$ & $1.62^{\mathrm{a}}$ & $1.05^{d}$ & $1.11^{c}$ & 0.09 & $p<0.05$ \\
\hline Sperm motility (\%) & $48.1^{d}$ & $75.4^{\mathrm{a}}$ & $54.4^{c}$ & $60.9^{b}$ & 8.11 & $p<0.05$ \\
\hline Plasma urea (mg/dL) & $19.2^{b}$ & $23.1^{\mathrm{a}}$ & $18.9^{b}$ & $19.3^{b}$ & 1.42 & $p<0.05$ \\
\hline Plasma protein $(\mathrm{g} / \mathrm{dL})$ & $7.28^{c}$ & $8.18^{a}$ & $7.76^{\mathrm{b}}$ & $7.50^{\mathrm{bc}}$ & 0.20 & $p<0.05$ \\
\hline Daily gain (kg/day) & $0.43^{b}$ & $0.47^{b}$ & $0.53^{a}$ & $0.54^{\mathrm{a}}$ & 0.07 & $p<0.05$ \\
\hline Testosterone concentration (ng/mL) & $7.07^{c}$ & $10.3^{a}$ & $9.03^{b}$ & $1.64^{d}$ & 0.01 & $p<0.05$ \\
\hline
\end{tabular}

a,b,c,dDifferent superscript on the same row shows the significant differences $(p<0.05)$

$\mathrm{T} 0=$ control ration (elephant grass $+5 \mathrm{~kg} / \mathrm{head} /$ day commercial concentrate), $\mathrm{T} 1=$ control ration $+150 \mathrm{~g}$ protected protein supplement SOYXYL ( $3 \%$ of concentrate), T2 = control ration $+300 \mathrm{~g}$ SOYXYL ( $6 \%$ of concentrate) and T3= control ration + 450 g SOYXYL ( $9 \%$ of concentrate). 
increased the supply of $\mathrm{N}$ for the rumen microbes, thereby increasing rumen microbial proliferation. Therefore, the latter condition may increase the microbial protein entering the intestine and increase the supply of $\mathrm{N}$ in the intestine and thus increased the $\mathrm{N}$ concentration in the plasma.

\section{Blood Plasma Urea}

Plasma urea concentration has been used as the indicator of protein breakdown; an increased plasma urea level may indicate the increased protein degradation. In this current work, plasma urea concentration of Simmental bulls was significantly $(p<0.05)$ affected by dietary supplementation of SOYXYL, in which SOYXYL supplementation at $3 \%$ from diet resulted in increased plasma urea concentration (Table 1). The plasma urea concentrations across treatment groups in this study was within the normal range (26.6 to $56.7 \mathrm{mg} / \mathrm{dL}$ ) according to Nozad (2012). Therefore, the increased plasma urea level in bulls supplemented with 3\% SOYXYL did not seem to negatively affect the bull's performance. This inference was supported by the fact that SOYXYL supplementation increased the daily gain of Simmental bulls. Therefore, the increased plasma urea concentration in the bulls supplemented with 3\% SOYXYL was most likely due to the homeostatic mechanisms for maintaining the level of urea in the blood of bulls (Steward and Smith, 2005).

\section{Daily Gain}

The present study has shown that supplementing $6 \%$ and $9 \%$ SOYXYL in the diet increased $(p<0.05)$ the average daily gain of Simmental bulls compared to control (Table 1). It seemed that feeding rumen-protected protein, such as SOYXYL, eliminated the protein loss (due to the transformation of dietary protein into microbial biomass) and thus, increased the availability of protein or amino acids for the host. Kamalak et al. (2005) suggested that avoiding dietary protein from ruminal fermentation allowed more amino acids to reach the small intestine and supply more absorbable amino acids per unit of absorbable energy. Since amino acids are the most critical nutrient for tissue biosynthesis, the increased supply of absorbable amino acids may therefore increase the growth rate of bulls (Uddin et al., 2015). Also, application of rumen-protected protein may be attributed to the decreased energy loss due to ruminal fermentation (Kamalak et al., 2005). Therefore, the latter condition may be associated with the increased energy supply for growth and development.

\section{Sperm Concentration}

It was shown in the present study that feeding ration supplemented with 3\% SOYXYL increased $(p<0.05)$ the concentration of sperm of Simmental bulls when compared to control (Table 1). The increase may be due to the increased intake of particular amino acids, such as arginine in SOYXYL. Arginine is an amino acid that is mostly found in soybean protein (Gorissen et al., 2018), which is the raw material of the SOYXYL. According to Shimizu et al. (2018), arginine is a biochemical precursor in the synthesis of putrescine, spermidine and spermine, and is essential for spermatogenesis and sperm motility. Therefore, feeding diet containing high level of arginine may improve reproductive performance due to the increasing synthesis of polyamine-polyamine and argininerich protein that are mostly found in sperm cells. Moreover, the increased available protein or amino acids for Simmental bulls is also responsible to increase sperm concentration in T1 bulls, as Cheah and Yang (2011) suggested that adequate protein is crucial for maintaining the normal function of both gonadal organs and spermatogenesis that are reflected by the development of testicles and the number of spermatozoa.

Interesting result was found in the present study; SOYXYL supplementation at $6 \%$ and $9 \%$ 
decreased $(p<0.05)$ the concentration of sperm of Simmental bulls (Table 1 ). Earlier study by Shelke et al. (2012) reported that dietary supplementation of rumen-protected protein improved efficiency of energy utilization in the ruminant. This condition may eventually increase the remaining energy and induce the lipogenesis in the liver and adipose tissue of bulls. The bulls for this study were not in the growing phase, so lipogenesis may be more dominant than protein biosynthesis. Therefore, the increased weight in the treated bulls in the current study could be mainly due to fat deposition instead of muscle protein deposition. In accordance with our finding, another recent study also revealed that high protein feeding may induce de novo lipogenesis in healthy humans (Charidemou et al., 2019). However, lipogenesis could make Sertoli cell resistant to insulin hormone (Rato et al., 2012). Such insulin resistance will inhibit the entry of nutrients, especially glucose, into the Sertoli cells, leading to improper development of the cells. As a result, it could compromise spermatogenesis which, in this study, was reflected in the decrease in the spermatozoa concentration. Elmaz et al. (2007) noticed that dietary high protein levels resulted in a lower concentration of spermatozoa in rams. Figure 1 shows the relationship between daily gain and sperm concentration of Simmental bulls in the present study. The figure implicitly shows that the increased daily gain (due to lipogenesis) implied in the decreased sperm concentration of Simmental bulls.

\section{Testosterone Hormone}

It was evident that the concentration of testosterone was higher $(p<0.05)$ in the bulls receiving $3 \%$ and $6 \%$ SOYXYL in the rations (Table 1). In general, protein is essential for the development of gonadal organs. In this regard, Elmaz et al. (2007) pointed out that adequate protein is crucial for testicular characteristic of ram lambs. Taken together, dietary supplementation of $3 \%$ and $6 \%$ SOYXYL may improve the protein status of bulls and, therefore, increase the concentration of testosterone of Simmental bulls in the present study. Unlike $\mathrm{T} 1$ and $\mathrm{T} 2$, the concentration of testosterone was lower $(p<0.05)$ in T3 bulls. As discussed earlier, the high levels of SOYXYL supplementation may be attributed to the induced lipogenesis and thus reduced the sensitivity of gonadal cells to insulin. Kelly and Jones (2013) suggested that the reduced insulin sensitivity may be attributed to the decreased testosterone production by Leydic cells. Similarly, Elmaz et al. (2007) reported that feeding high protein diet resulted in a lower testosterone concentration in rams. The latter author further explained that high-protein diet may increase fat deposition in the scrotum that can disrupt thermoregulation in the scrotum as well as spermatogenesis and testosterone production. Regarding sperm concentration, the excessive levels of available protein due to SOYXYL supplementation (9\%) seemed to increase lipogenesis and daily weight gain of bulls, and eventually decrease the production of testosterone hormone by Leydig cells (Figure 1).

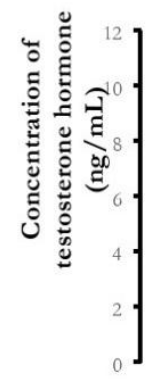

(A)
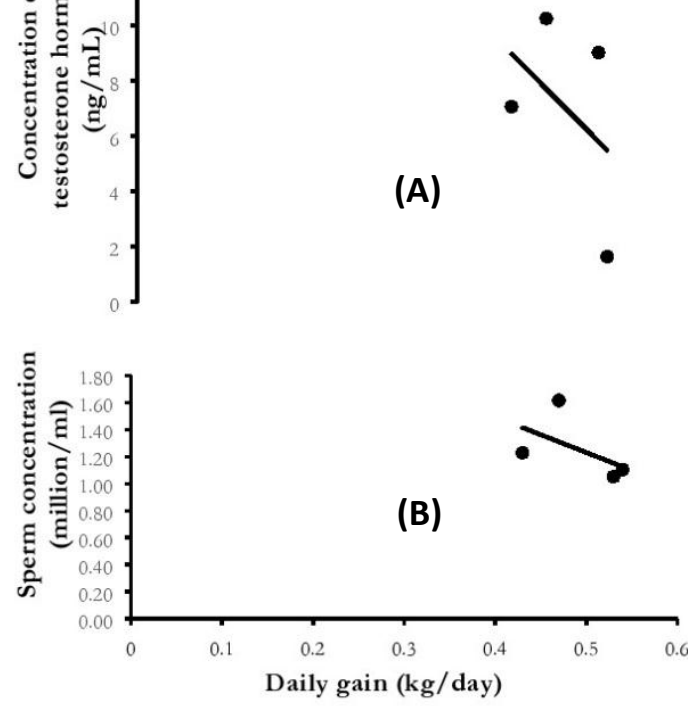

Figure 1. Relationship between daily gain and concentration of testosterone hormone (A) and sperm concentration (B) in Simmental bulls. 


\section{Sperm Motility}

Data in the current study showed that dietary supplementation of SOYXYL increased $(p<0.05)$ the sperm motility of Simmental bulls (Table 1). Supplementation of SOYXYL, which was associated with the increased protein available for the bulls, may increase the sperm motility of bulls as Hosseini and Eslamian (2014) revealed that the available amount of protein in rations can affect the reproductive quality of bulls including sperm motility. The available protein may also serve as an antioxidant that can protect the spermatozoa against oxidation (Patricio et al., 2016). The latter authors further suggested that antioxidant protein may contribute to the increased sperm motility and normal semen viscosity. The amino acid arginine has also been reported to play a crucial role in increasing the sperm motility and capacitation. According to Maidin et al. (2014), arginine (together with vitamin E) increased the production of nitric oxide that can stimulate glucose metabolism and adenosine triphosphate (ATP) production in the sperm. The latter condition may eventually increase the motility of spermatozoa.

\section{Conclusions}

Dietary supplementation of SOYXYL at the level of $3 \%$ increased plasma protein, testosterone, sperm concentrations and sperm motility. However, supplementation of SOYXYL at $6 \%$ and $9 \%$ decreased the concentrations of sperm and testosterone.

\section{Acknowledgments}

The authors would like to thank the LPPM of Diponegoro University for funding this research project No. 385-38/UN7.P4.3/PP/2018 (Fiscal Year 2018), and the Artificial Insemination Station, Central Java Province Indonesia for having collaborated in this project.

\section{Conflict of Interests}

The authors hereby confirm that there is no conflict of interest in this research.

\section{References}

Aboozar M and F Niazi. 2013. Effects of rumen undegradable protein on productive performance and $\mathrm{N}$ balance of Holstein cows in early postpartum period. Iran. J. Appl. Anim. Sci. 3: 657665.

http://ijas.iaurasht.ac.ir/article_513422_104bbb7 01fba3a8a2cfc68668056dfb4.pdf

Ahlman B, M Charlton, A Fu, C.Berg, P O'Brien and KS Nair.2001. Insulin's effect on synthesis rates of liver proteins. A swine model comparing various precursors of protein synthesis. Diabetes 50: 947954.

https://doi.org/10.2337/diabetes.50.5.947

Charidemou E, T Ashmore, X Li, BD McNally, JAWest, S Liggi, M Harvey, E Orford and JL Griffin. 2019. A randomized 3-way crossover study indicates that high-protein feeding induces de novo lipogenesis in healthy humans. JCl Insight. 4(12): 124819. https://doi.org/10.1172/jci.insight.124819

Cheah Y and W Yang. 2011. Functions of essential nutrition for high quality spermatogenesis. Adv. Biosci. Biotechnol. 2: 182-197. DOI:10.4236/abb.2011.24029

Elmaz O, U Cirit , U Keser , K Gürbulak , K Güvenç and $C$ Kutay. 2007. Effect of two dietary protein levels on testosterone, testicular parameters and semen quality in ram lambs during pubertal development. Med. Wet. 63: 1177-1180.

Gorissen SHM, JJR Crombag, JMG Senden, WAH Waterval, J Bierau, LB Verdijk and LJCV Loon. 2018. Protein content and amino acid composition of commercially available plantbased protein isolates. Amino Acids. 50: 16851695. https://doi.org/10.1007/s00726-018-26405

Hosseini B and G Eslamian. 2014. Association of dietary factors with male and female infertility: review of current evidence. Thrita 3(3): e20953. https://doi.org/10.5812/thrita.20953

Hristov AN, A Bannink, LA Crompton, P Huhtanen, M Kreuzer, $M$ McGee, $P$ Nozière, CK Reynolds, AR Bayat, DR Yáñez-Ruiz, J Dijkstra, E Kebreab, A Schwarm, KJ Shingfield and Z Yu. 2019. Invited review: Nitrogen in ruminant nutrition: A review of measurement techniques. J. Dairy Sci. 102: 5811-5852. https://doi.org/10.3168/jds.2018-15829

Hungate RE. 1966. The Rumen and Its Microbes. Academic Press, New York. 
Irfan IZ, A Esfandiari and C Choliq. 2014. Profil protein total, albumin, globulin dan rasio albumin dan globulin sapi pejantan. Jurnal Ilmu Ternak dan Veteriner 19(2): 123-129.

http://dx.doi.org/10.14334/jitv.v19i2.1040

(article in Indonesian language)

Kamalak A, Ö Canbolat, Y Gurbuz and O Özay. 2005. Protected protein and amino acids in ruminant nutrition. KSU. J. Scie. Eng. 8(2)-2005.

Kelly DM and TH Jones. 2013. Testosterone: a metabolic hormone in health and disease. J. Endocrinol. 217: R25-45. https://doi.org/10.1530/JOE-12-0455

Kumar R, D Kar, D Kumar, V Singh and S Sihag. 2018. Effect of rumen protected amino acids and fish meal on feed conversion ratio of Murrah buffalo heifers. Int. J. Curr. Microbiol. Appl. Sci. 7: 25872595.

https://doi.org/10.20546/ijcmas.2018.703.299

Lapierre $\mathrm{H}$ and GE Lobley. 2001. Nitrogen recycling in the ruminant: A Review. J. Dairy Sci. 84(E. Suppl.):E223-E236

https://doi.org/10.3168/jds.S00220302(01)70222-6

Ma H, J Cheng, X Zhu and Z Jia. 2011. Effects of rumen-protected tryptophan on performance, nutrient utilization and plasma tryptophan in cashmere goats. Afr. J. Biotechnol. 10: 58065811. http://www.academicjournals.org/AJB https://doi.org/10.5897/AJB10.393

Maidin MS, NF Adanan, MT Aminudina and A Tawang. 2014. In vitro supplements improves motility and progressive score of spermatozoa in Jermasia goats. APCBEE Procedia 8: 329-333. https://doi.org/10.1016/j.apcbee.2014.03.049

Nozad S, A Ramin, G Moghadam, S Asri-Rezaei, A Babapour, and S Ramin . 2012. Relationship between blood urea, protein, creatinine, triglycerides and macro-mineral concentrations with the quality and quantity of milk in dairy Holstein cows. Vet Res Forum. 2012 Winter; 3(1): 55-59.

https://www.ncbi.nlm.nih.gov/pmc/articles/PMC 4312820/?report=classic

Patricio A, DF Cruz, JV Silva, A Padrão, BR Correia, L Korrodi-Gregório, R Ferreira, N Maia, S Almeida, J Lourenço, V Silva and M Fardilha. 2016. Relation between seminal quality and oxidative balance in sperm cellsRelação entre a qualidade seminal e o equilíbrio oxidativo nos espermatozoides. Acta Urol. Port. 6-15. https://doi.org/10.1016/i.acup.2015.10.001

Prasetiyono BWHE, A Subrata, BIM Tampoebolon, Surono, and Widiyanto.2018. In vitro ruminal degradability of soybean meal protein protected with natural tannin. IOP Conf. Ser.: Earth Environ. Sci.

119(1). https://iopscience.iop.org/article/10.1088/17551315/119/1/012016

Prasetiyono BWHE, Suryahadi, T Toharmat and R Syarief. 2007. Strategi suplementasi protein ransum sapi potong berbasis jerami dan dedak padi. Med. Pet. 30: 207-217. http://medpet.journal.ipb.ac.id/index.php/media peternakan/article/view/946

Radostits OM, CC Gay, KW Hinchcliff and PD Constable. 2007. Veterinary Medicine: A textbook of the diseases of cattle, sheep, pigs, goats, and horses 10 Edition, Elsevier Health Sciences, Philadelphia, PA, USA.

Rato L, MG Alves, S Socorro, AI Duarte, JE Cavaco and PF Oliveira. 2012. Metabolic regulation is important for spermatogenesis. Nat. Rev. Urol. 9: 330-338.

https://doi.org/10.1038/nrurol.2012.77

Rekwot PI, EO Oyedipe, PM Dawuda and VO Sekoni.1997. Age and hourly related changes of serum testosterone and spermatogenesis of prepubertal bulls fed two levels of nutrition. Vet. J. 153: 341-347.

https://doi.org/10.1016/S1090-0233(97)80068-8

Roseler DK, JD Ferguson, CJ Sniffen and J Herrema. 1993. Dietary protein degradability effect on milk urea nitrogen and non protein nitrogen in Holstein cows. J. Diary Sci. 58: 525-534. https://doi.org/10.3168/jds.S00220302(93)77372-5

SAS. 2009. SAS User's Guide. SAS Institute Inc, SAS Campus Drive, Cary, NC 27513.

Shelke SK, SS Thakur and SM Shete. 2012. Protected nutrients technology and the impact of feeding protected nutrients to dairy animals: a review. Int. J. Dairy Sci. 7: 51-62. https://doi.org/10.3923/ijds.2012.51.62

Shimizu A, T Mitani, S Tanaka, H Fujii, M Maebuchi, Y Amiya, Y Tanaka, Y Matsui, S Nakamura and S Katayama. 2018. Soybean-derived glycinearginine dipeptide administration promotes neurotrophic factor expression in the mouse brain. J. Agric. Food Chem. 66: 7935-7941. https://doi.org/10.1021/acs.jafc.8b01581

Steward GS and CP Smith. 2005. Urea nitrogen salvage mechanisms and their relevance to ruminants, non-ruminants and man. Nutr. Res. Rev. 18:

4962. https://doi.org/10.1079/NRR200498

Steel, R.G.D., J.H. Torrie, and D.A. Dickey. 1996. Principles and Procedures of Statistic: A Biometrical Approach. McGraw-Hill College.

Tedeschi LO, DG Fox, MA Fonseca and LFL Cavalcanti. 2015. Models of protein and amino acid requirements for cattle. Rev. Bras. Zoo. 44(3). http://dx.doi.org/10.1590/S180692902015000300005 
Toelihere MR. 1993. Inseminasi Buatan pada Ternak. Penerbit Angkasa, Bandung (article in Indonesian language)

Uddin MJ, ZH Khandaker, MJ Khan and MMH Khan. 2015. Dynamic of microbial protein synthesis in the rumen - A Review. Ann. Vet. Anim. Sci. 2: 116-131.

http://naturepub.org/index.php/journal/navas
Voller A, DE Bidwell and A Bartlett. 1989. The enzyme linked immunosorbent assay (Elisa). A guide with abstract of microplate aplications. Proc. Zool. Soc. London; 1989. pp: 506-512.

Yasothai R. 2014. Importance of protein on reproduction in dairy cattle. Int. J. Sci. Environ. Technol. 3: 2081-2083. 